\title{
A Mini Review on Realist Perception in Early Drama
}

\section{Sabah H Ahmed* and Nasirin Abdillah}

Faculty of Creative Technology and Heritage Studies, University Malaysia Kelantan, Malaysia

*Corresponding author: Sabah H Ahmed, Faculty of Creative Technology and Heritage Studies, University Malaysia Kelantan, Malaysia, Tel: +927809225164; E-mail: sabah.h.alyousif@gmail.com

Received date: July 7, 2018; Accepted date: July 17, 2018; Published date: July 23, 2018

Copyright: $\odot 2018$ Ahmed SH, et al. This is an open-access article distributed under the terms of the Creative Commons Attribution License, which permits unrestricted use, distribution, and reproduction in any medium, provided the original author and source are credited.

\begin{abstract}
This review elucidated the theory of realism under two categories. The first category was the romantic realism, while the second category is the true realism. The former involves drama with idealized subjects mounted in extremely detailed and historically accurate settings with costumes. However, in the second category called true realism, the plays based on non-idealized contemporary subjects were presented in settings designed to reveal a significant interaction of the character's environment and action. This concept therefore provided a truthful representation of the real world which is based on direct observation of contemporary life and manners.
\end{abstract}

Keywords: Romantic realism; True realism; Early drama; Realist

\section{Introduction}

Comte was the principal theorist of realism who founded the concept of positivism [1]. He encouraged one to find explanation or the truth based on objective observation and scientific analysis [2]. The advocates of the theory of realism agree that this concept provided a truthful representation of the real world which is based on the direct observation of contemporary life and manners. In realism the author must be impartial in his approach toward the subject matter. Realists see drama as a means to depict the truthful nature of life. It is a way to get the audience question their own assumptions as well as the societal norm when the social issues are addressed. Hill [3] is another proponent of realism. He reported that "the realist...sees life in terms of what it might be, as well as in terms of what it is to be. He aims to hasten the age of beauty and peace by delineating the ugliness and warfare of the present; but ever the converse of his picture rises in the mind of the reader". The early realists might seem a lot more like romantics because of their adherence to historical facts, social reality and physical appearance of highly emotional treatments. All of these traits were the common grounds that early realists shared with romantics.

In the 19th century, the romantic and true realism were the two identified strains of realism [2]. The first strain was romantic realism, in which drama with idealized subjects were mounted in an extremely detailed and historically accurate settings with costumes. The second strain is called true realism, in which plays based on non-idealized contemporary subjects were presented in settings designed to reveal a significant interaction of the character's environment and action [4]. The two strains will be discussed further in the succeeding sections.

\section{The Romantic Realism}

In romantic realism, the dramatist always tries to perfect the realities it depicts. The playwrights use realistic settings, costumes and props in their productions. In this study the romantic realist was described in relation to the picture-frame stage, special effects, box set and lighting.
The origin of romantic realism can be found in the picture-frame stage. This stage was perfected in Italy in the 16th and 17th centuries [5]. It was considered realistic since it sought to create the illusion of a single place. The special effect was also emphasized in line with the movement toward accuracy of details. An example of this was Pixerecourt who managed to create the special effect of flood (Daughter of the Exile) and volcanic eruption (Death's Head) on stage. His plays were considered very creative in inventing special effects [6]. Dion Boucicault, on the other hand, made ghosts appear and disappear though the stage floor [7]. His special effect of depicting a house on fire was considered the "most exciting and realistic" [7]. Moreover, the box set was introduced as dramatists began to bring real life dramas on stage. The set consists of a three-walled box which portrayed an actual room, with the fourth wall removed [8]. This innovation enabled the set to be furnished with carpets, furniture and belongings and decorated like a real room. Hence, the actors were able to speak in conversations with each other, without regard to the audience and act like they are enclosed in a private space. The concept of realism and lighting could be traced back to 1820 when gas lighting was introduced which helped in creating illusions on stage. Dramatists were then able to create effects of sunlight, sunset, lightning and storms convincingly [9].

\section{The Romantic Realism Movement in Western Nations}

It would be incomplete to discuss romantic realism without mentioning its movement in France which was perfected in France by Victorien Sardou. He was the most popular playwright of his era. His earliest works included comedies such as A Scrap of Paper and Our Intimates as well as mild satires on contemporary life such as The Family Benoiton. Sardou also wrote historical plays in which he worked out every aspect (setting, properties, costumes) comprehensively [10].

In England, on the other hand, the pioneer of romantic realism was Charles Macready who took over the English theater from the 1830s to the 1840s. He sought historical consistency in preparing his costumes, props, as well as painted scenes for his productions [11]. David Garrick was another director who contributed to romantic realism. Garrick returned to England in 1765 and brought with him a new idea, which 
was to design settings specifically for particular plays. Hence, he hired scene painters to work on his sets [12]. Henry Irving was another key figure responsible for raising romantic realism to new heights in England. He managed to incorporate lighting in his stage design and scenic illusion.

In Germany, the likes of Johann Wolfgang von Goethe and Ludwig Tieck (were the most prominent names in romantic realism. Musicdrama was introduced in Germany during this period, which was claimed to be more superior to spoken drama [13]. The years between 1874 and 1890, depicted the success of a company called the Meiningen Players. The producer of this company, Georg II, the Duke of Saxe-Meiningen, aimed to create a perfect illusion from reality, much like many other producers of his day. Their work fitted more into the category of romantic realists because he was very particular in designing costumes, settings, and scenery which were incorporated using three-dimensional elements and authentic props. Augustin Daly was responsible for the development of American realism [14]. He insisted on accurate and detailed settings, properties, and costumes, just like Saxe-Meningen. He contributed to the final phase of romantic realism in which traditional plays were presented with accurate settings and authentic costumes [15].

\section{The True Realism}

True realists believed that art should depict in real life, contemporary social issues, and objectivity in portraying the subject matter. In true realism, the setting acts as an integral part of the action rather than just a picturesque background. Note that in romantic realism, playwrights placed more importance on accuracy of details rather than the action itself. It was around 1853 that directors began to progress toward true. Nevertheless, it would be a long time before a truly realistic drama was created in western countries as highlighted in the succeeding sections.

\section{True Realism Movement in Western Countries}

In France Adolphe Montigny, who was the director of the Gymbase Theater in Paris was the first to take a bold step toward directing according to the true realism [16]. He made the actors speak to each other rather than to the audience (which was common practice) and arranged this settings like real furnished rooms. His actors were asked to sit on the furniture when appropriate and he did not use the "traditional patterns of posing and moving on the stage".

However, in England, the concept of true realism was associated with Squire Bancroft, his wife, Marie Effie Wilton Bancroft, and Tom Robertson. They adopted a no-star approach in casting with a full adherence to the box setting, which was furnished.. They managed to capture the attention of mid-Victorian audiences and their plays were considered realistic. Interestingly, they paid attention to detail, created realistic sets and extended realism to acting style, dialogue and theme of their plays.

The 1870-1890s was considered the era of "The New Drama". Henrik Ibsen, was one of the key figures in the realistic which earned him the name "father of modern drama". His early works in the Norwegian theaters promoted nationalism from his works was made up of romantic dramas; mostly Norwegian legend, fairy tales and sagas. Ibsen was concerned with the bases of human happiness and insisted on cutting through taboos and hypocrisies. Some consider Ibsen's realistic plays as not completely realistic because they were packed with ambiguities which promote multiple interpretations. His most realistic drama included written between 1877 and 1890. These include Pillars of Society, A Doll's House, Ghosts, An Enemy of the People, The Wild Duck, Romersholm, Lady from the Sea and Helda Gabler [17].

Strindberg was another famous writer after Hoenrik Ibsen, who introduced the modern drama. Aside from being recognized as the "leader of the move to realism" [18]; he was also a figure for the modern breakthrough generation in Sweden. This was particularly due to his "commitment to realism" and his "outspoken public voice" [19]. He therefore came up with a new concept, which was later known as the Strindbergian realism, which was basically a modern, "psychological realism" [20]. It was also claimed that Strindberg was inspired by a Danish critic, Georg Brandes, who proposed strongly that literature should deal with contemporary issues such as class, marriage and sexuality.

\section{Conclusion}

A realist sees drama as a means to depict the truthful nature of life. It is a way to get the audience question their own assumptions as well as the societal norm when the social issues are addressed. This review addressed the two concepts of realism viz: romantic and true realism. This review concluded that realism theory provided a truthful representation of the real world which is based on the direct observation of contemporary life and manners. Hence, the application and approach to this concept must be observed in an impartial way in relation to the subject matter.

\section{References}

1. Comte AB (1974) The positive philosophy of Auguste Comte freely translated and condensed by Harriet Martineau. AMS Press, New York.

2. Stedman JG, Claeys G (2011) The Cambridge History of NineteenthCentury Political Thought. The Cambridge History of Political Thought. Cambridge University Press, United Kingdom

3. Hill PG (1991) Our dramatic heritage: Reactions to realism. Associated University Press, USA

4. Leach R (2004) Makers of modern theatre: An introduction. Routledge, UK.

5. Gordon R (2006) The purpose of playing: Modern acting theories in perspective. Ann Arbor, University of Michigan Press, USA.

6. Roberts VM (1971) The nature of theatre. Harper \& Row, New York.

7. Ward AW, Waller AR, Trent WP, Erskine J, Sherman SP, et al. (2000) The Cambridge history of English and American literature: An encyclopedia in eighteen volumes. Bartleby.com, New York.

8. Lacey S (1995) British realist theatre: The new wave in its context 1956-1965. Routledge, UK.

9. Moran M (2006) Victorian literature and culture: Introductions to British literature and culture series. Continuum International Publishing Group, UK.

10. Kuritz P (1988) The making of theatre history. Prentice Hall, USA.

11. McConachie B, Zarilli P, Williams GJ, Sorgenfei CF (2010) Theatre histories: An introduction. (2ndedn), Taylor \& Francis, UK.

12. Yardley K (1997) Role play: Theory and practice. Sage Publications, London.

13. Grey TS (1995) Wagner's musical prose: Texts and contexts. Cambridge University Press, UK.

14. University of California (1855) Putnam's Magazine: Original papers on literature, science, art, and national interests. G.P. Putnam \& Co., New York.

15. Styan JL (1983) Modern drama in theory and practice 1: Realism and naturalism. Cambridge University Press, UK. 
Citation: Ahmed SA, Abdillah N (2018) A Mini Review on Realist Perception in Early Drama. Arts Social Sci J 9: 379. doi: 10.4172/2151-6200.1000379

Page 3 of 3

16. DeVries LP (1913) A comparison of the realism in the modern French novel and drama. University of Wisconsin, USA.

17. Larsen DL (2000) The company of the creative: A Christian reader's guide to great literature and its themes. Kregel Academic, USA.

18. Henrik I (2005) A Doll’s House. Prestwick House Inc, US.
19. Warme LG (1996) A history of Swedish literature. University of Nebraska Press, USA.

20. Chambers $C$ (2006) Continuum companion to twentieth century theatre. Continuum International Publishing Group, London. 